\title{
Distribution of lithium and fluorine in lujavrites from the Ilímaussaq intrusion
}

\author{
John C. Bailey, Raymond Gwozdz, John Rose-Hansen, Lars Skov Andersen and \\ Henning Sørensen
}

The development of a relatively rapid neutron activation technique, involving fasttransfer of samples from the reactor followed by Cerenkov counting, has allowed us to extend the analytical coverage of $\mathrm{Li}$ and $\mathrm{F}$ in the Ilímaussaq lujavrites and their minerals. On geological grounds the lujavrites have been regarded as crystallising from the final agpaitic magmas at Ilímaussaq. In agreement with this, contents of $\mathrm{Li}$ and $\mathrm{F}$ - which are normally maximal in residual magmas - have been shown to attain their highest levels within the lujavrites (Gerasimovsky, 1969; Ferguson, 1970). However, these studies failed to agree on the absolute contents of $\mathrm{Li}$ in the lujavrites. For aegirine lujavrite and arfvedsonite lujavrite, Gerasimovsky (1969) reported averages of 155 and $791 \mathrm{ppm}$, respectively, whereas Ferguson (1970) found only 90 and $226 \mathrm{ppm}$. Hamilton (1964) only reported $80 \mathrm{ppm} \mathrm{Li}$ in a single sample of arfvedsonite lujavrite.

More recent mapping within the intrusion has revealed further divisions within the lujavrite sequence (Sørensen et al., 1969; 1974; Demin, 1971; Engell, 1973; Andersen \& Bohse, 1978 , this volume). These subdivisions provide an increased geological control for the interpretation of $\mathrm{Li}$ and $\mathrm{F}$ data. Samples of the various lujavrite varieties were taken from the drill cores obtained in 1958, 1962 and 1969.

In the southern half of the intrusion, aegirine lujavrite I is concordant with the (uppermost) transitional layered kakortokites and like them shows mineralogical layering and a relatively high content of eudialyte. It passes upwards into aegirine lujavrite II and arfvedsonite lujavrite (samples from Tunugdliarfik). In the Kvanefjeld area, the early fine-grained lujavrites are mainly arfvedsonite lujavrites, but they include locally developed naujakasite and villiaumite-bearing lujavrites. They are cut by sheets of medium- to coarse-grained (M-C) lujavrite, the final major intrusion of the whole massif.

\section{Analytical techniques}

$\mathrm{Li}$ is normally unobtainable by instrumental neutron activation analysis since its irradiation yields $\mathrm{Li}^{8}$ which has a half-life of $0.84 \mathrm{sec}$ and emits only B-particles with a maximum energy of $13 \mathrm{MeV}$. These problems were surmounted by using a fast transfer system and Čerenkov counting (Heydorn et al., 1977).

Silicate rock samples of $0.3 \mathrm{~g}$ were irradiated in the Danish Reactor DR-2 for $1.6 \mathrm{sec}$ and after $0.3 \mathrm{sec}$ decay time (used for transportation of the sample), it was counted for $30 \mathrm{sec}$. The Čerenkov detector was coupled to a single-channel analyser operating as a low-level discriminator, and pulses were counted by means of a multichannel analyser operating in the multiscaling mode with $0.1 \mathrm{sec}$ time interval per channel. Three components could be 
resolved from the decay spectrum: $\mathrm{Li}^{8}$ with $\mathrm{t}_{1 / 2}=0.84 \mathrm{sec}, \mathrm{N}^{16}$ with $\mathrm{t}_{1 / 2}=7.14 \mathrm{sec}$ and a long-lived background component.

The first component was resolved with the greatest precision. Standard Li solutions were used to calibrate samples and reference standards. Empirical values for sensitivity and precision were found to be $0.2 \mathrm{ppm}$ and $\pm 10-15 \%$, respectively.

Accuracy for the $\mathrm{Li}$ technique can be judged from results for NIM-L (lujavrite) - an international geochemical standard. Nineteen analyses, obtained at different times in the analytical programme, gave an arithmetic average of $45.0 \mathrm{ppm} \mathrm{Li}$, coefficient of variation 6.4\%. The proposed Li content of this standard has recently fallen from $70 \mathrm{ppm}$ (Russell $e t$ al., 1972) to $48 \mathrm{ppm}$ (Steele et al., 1978). In close agreement with our result, Sten Lou (personal communication, 1979) obtained a value of $43 \mathrm{ppm} \mathrm{Li} \mathrm{using} \mathrm{atomic} \mathrm{absorption}$ spectrometry.

The second component in the decay spectrum - isotope $\mathrm{N}^{16}$ - is generated in the sample in three different ways:

$$
\begin{aligned}
& N^{15}(n, \gamma) N^{16} \\
& O^{16}(n, p) N^{16} \\
& F^{19}(n, \alpha) N^{16}
\end{aligned}
$$

The contribution from $\mathrm{N}^{15}$ is insignificant while the minor contribution from $\mathrm{O}^{16}$ was subtracted by assuming $48 \%$ oxygen in all the silicate rock samples. The remaining $F$ contribution was then calibrated using international geochemical standards with $0.2-3.4 \% \mathrm{~F}$. The counting techniques were optimised for $\mathrm{Li}$, and consequently the $\mathrm{F}$ results can only be considered accurate to approximately $\pm 20 \%$. The sensitivity is about $500 \mathrm{ppm}$ F. Re-analysis under more suitable counting conditions would improve the $F$ results considerably. Unfortunately, reactor DR-2 has been closed down, and since reactor DR-3 produces mainly thermal neutrons the reaction $F^{19}(n, \alpha) N^{16}$ is seriously inhibited.

Fluorine analyses were also undertaken with a specific ion (F) electrode after either $\mathrm{Na}_{2} \mathrm{CO}_{3}$ fusion or water extraction. The two preparation techniques yielded results within the uncertainty of the method, stated to be $\pm 10-15 \%$. Accuracy was tested by analysis of the

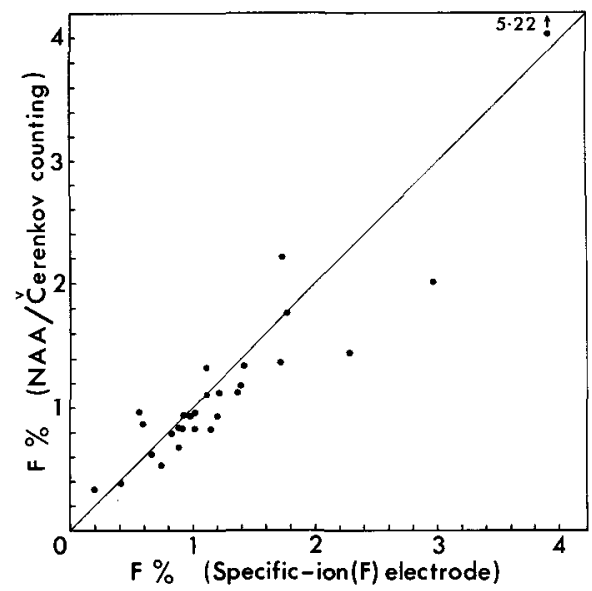

Fig. 1. Comparison of $F$ analyses by neutron activation analysis plus Čerenkov counting, and specificion $(F)$ electrode on villiaumite-bearing lujavrite, Kvanefjeld, Ilímaussaq intrusion. 
Table 1. Median and mean Li and F values (ppm) for Ilímaussaq lujavrites, and corresponding regression values

\begin{tabular}{|c|c|c|c|c|c|c|c|c|c|c|}
\hline \multirow[t]{2}{*}{ Lujavrite type } & \multirow[t]{2}{*}{ Samples } & \multicolumn{3}{|c|}{$\mathbf{L}_{i}$} & \multicolumn{3}{|c|}{$\mathrm{F}$} & \multicolumn{2}{|c|}{ Regression constants } & \multirow{2}{*}{$\begin{array}{c}\text { Coeff } \\
\text { of } \\
\operatorname{cor} r\end{array}$} \\
\hline & & Median & Mean & St. v & Median & Mean & St. J. & $\log _{a} \mathrm{Li}=$ & $=\frac{a \log F}{b}+b$ & \\
\hline $\begin{array}{l}\text { Aegirine lujavrite } 1 \\
\text { (Kangerdluarssuk) }\end{array}$ & 1.79 & 160 & - & - & 600 & - & - & - & - & - \\
\hline $\begin{array}{l}\text { Later aegirine lujarrite } \\
\text { (Tunugdliarfik) }\end{array}$ & 11 & 160 & - & - & 900 & - & - & - & - & - \\
\hline \multicolumn{11}{|l|}{ Arfuedsonite lujavrite } \\
\hline Tunugdiarfik & 19 & 620 & 780 & 620 & 1900 & 2800 & 2900 & 0.96 & -0.38 & 0.72 \\
\hline Subsample & 17 & 635 & 800 & 660 & 1900 & 2450 & 2150 & 1.02 & -0.55 & 0.85 \\
\hline Kvanefjeld & 18 & 750 & 730 & 190 & 8200 & 7650 & 3500 & -0.80 & 5.97 & 0.33 \\
\hline Subsample & 16 & 750 & 765 & 80 & 6800 & 7450 & 3650 & 0.23 & 2.00 & 0.63 \\
\hline$M-C$, Kvanef jeld & 39 & 760 & 820 & 160 & 2100 & 3000 & 2800 & 0.48 & 1.26 & 0.66 \\
\hline Subsample & 33 & 760 & 800 & 160 & 2450 & 3300 & 2950 & 0.35 & 1.70 & 0.85 \\
\hline \multirow[t]{2}{*}{$\begin{array}{l}\text { Naujakasite-bearing } \\
\text { (Kvanefjeld) }\end{array}$} & 18 & 700 & 660 & 150 & 4500 & 6700 & 5000 & - & - & - \\
\hline & & & & & \multicolumn{2}{|c|}{$11450^{*} 14000$} & 8000 & & & \\
\hline \multicolumn{11}{|c|}{ (Kvanefjeld) } \\
\hline \multirow[t]{2}{*}{ Subsample } & 17 & 775 & 790 & 60 & \multicolumn{2}{|c|}{$11000^{*} 13600$} & 8300 & 0.26 & 2.34 & 0.65 \\
\hline & & & & & 10600 & 13000 & 10500 & & & \\
\hline
\end{tabular}

* F by specific-ion electrode

Parameters for subsamples were obtained after eliminating individual samples which deviate significantly

from the preliminary regression line.

geochemical standards GSP-1 (3200 ppm F found, 3200 ppm recommended) and G-2 (1204 ppm found, $1290 \mathrm{ppm}$ recommended), Flanagan, 1976.

The preliminary $\mathbf{F}$ contents obtained by Čerenkov counting have been compared with values obtained using the specific ion electrode (Kunzendorf et al., 1973; analyst T. Lundgaard) on 28 samples of villiaumite-rich lujavrites from Kvanefjeld (fig. 1). The two techniques show reasonable agreement up to about $1.5 \% \mathrm{~F}$ (average difference $21 \%$ ) with a tendency for results from Čerenkov counting to be lower. Above $1.5 \%$, the results are markedly discordant (average difference $42 \%$ ). In our opinion, F analysis of geological materials via Čerenkov counting appears highly promising and justifies further investigation.

\section{Results and discussion}

\section{Li and $F$ distribution in rock types}

Table 1 and fig. 2 summarise the Li and F contents of the various lujavrite types from Ilímaussaq. Median Li values show an overall increase from $160 \mathrm{ppm}$ in aegirine lujavrite I from Kangerdluarssuk to $635 \mathrm{ppm}$ in arfvedsonite lujavrite from Tunugdliarfik to $760 \mathrm{ppm}$ in $\mathrm{M}-\mathrm{C}$ lujavrite from Kvanefjeld. In detail, however, Li only averages $160 \mathrm{ppm}$ in the later aegirine lujavrites which are contemporaneous with at least some of the arfvedsonite lujavrites, and the final M-C lujavrite from Kvanefjeld does not exhibit higher contents than the preceding arfvedsonite lujavrites of the same area. 


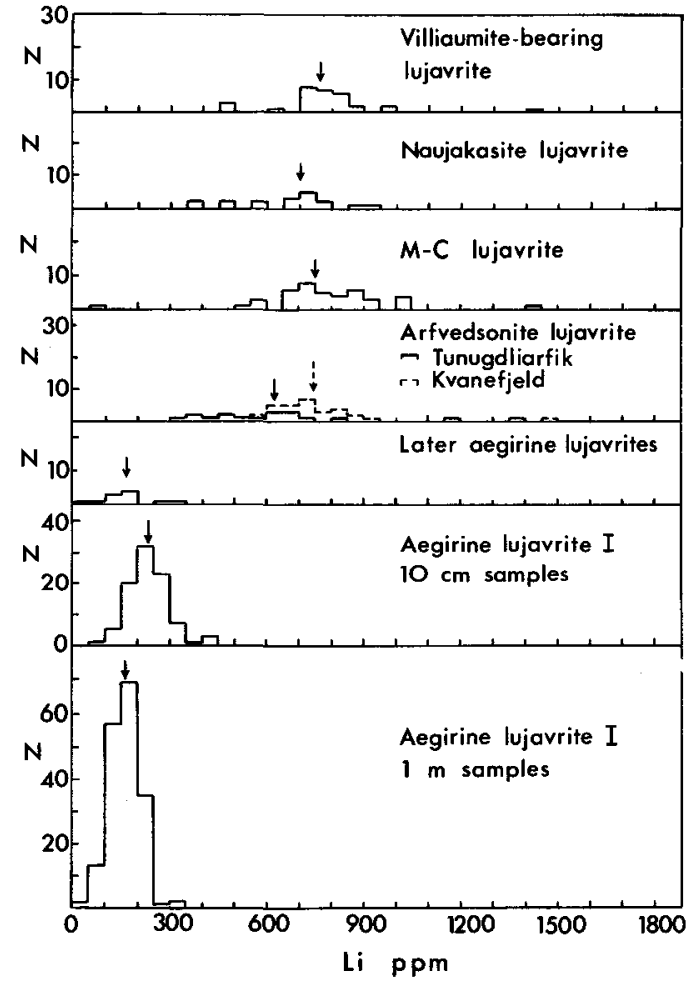

Fig. 2. Histograms of Li contents in lujavrite varieties, Ilímaussaq intrusion. Median values are indicated by arrows.

The present results are in fairly close agreement with those of Gerasimovsky (1969), since our averages for aegirine lujavrite and arfvedsonite lujavrite are 160 and $690 \mathrm{ppm} \mathrm{Li}$, respectively. The single result of $1192 \mathrm{ppm} \mathrm{Li}$ for M-C lujavrite reported by Gerasimovsky (1969) seems atypically high.

Fluorine values show the same increasing trend, in general, as $\mathrm{Li}$ but with the added complication that large volumes of lujavrite - generally arfvedsonite lujavrite - from Kvanefjeld drill cores contain up to 10 vol.\% (generally $1-4$ vol.\%) of villiaumite (NaF). Villiaumite-rich lujavrites average about $11000 \mathrm{ppm} F$ in contrast to about $2000 \mathrm{ppm}$ in nearby Kvanefjeld lujavrites free of villiaumite. The analyses of villiaumite-rich lujavrite were made on drill core samples in which the water soluble villiaumite showed no signs of dissolution by percolating ground water.

\section{Data scatter and sample heterogeneity}

Figure 2 illustrates that the scatter of $\mathrm{Li}$ contents also increases into the later lujavrite varieties. Part of this scatter may be due to sampling. Firstly, all the samples of aegirine lujavrite I were taken from a single drill core whereas the later lujavrites were obtained from a number of cores (18 in the case of M-C lujavrite). Secondly, the weight of the samples in relation to grain size varies considerably. Thus, $1 \mathrm{~m}$ (roughly $0.7 \mathrm{~kg}$ ) samples of fine-grained aegirine lujavrite I are compared with $0.2-0.4 \mathrm{~kg}$ samples of medium- to coarse-grained lujavrite. However, $0.2-0.4 \mathrm{~kg}$ samples of the fine-grained arfvedsonite lujavrites have 
Table 2. Li contents (ppm) in nodular lujavrites, Tunugdliarfik-Agpat area

\begin{tabular}{lcccc}
\hline Drill core no. & 5 & 6 & 6 & 6 \\
Depth $(\mathrm{m})$ & 43.47 & 38.2 & 38.58 & 72.78 \\
\hline Host (arfvedsonite lujavrite) & 698 & 2015 & 2322 & 871 \\
Rim of nodule (acmite-rich) & 289 & 1880 & 1047 & 513 \\
Core of nodule & 33 & 1030 & 1429 & 735 \\
\hline
\end{tabular}

virtually the same scatter as the $\mathrm{M}-\mathrm{C}$ lujavrite samples. In addition, $10 \mathrm{~cm}$ (i.e. only $0.07 \mathrm{~kg}$ ) splits of aegirine lujavrite I show only slightly more scatter than the $1 \mathrm{~m}$ samples. We conclude that the scatter of $\mathrm{Li}$ values in the later arfvedsonite and $\mathrm{M}-\mathrm{C}$ lujavrites is largely an innate geochemical feature of these lujavrite varieties rather than an artifact of sampling. Heterogeneity is also observed in thin sections where the contents of accessory Li-mica are very erratic. Heterogeneity of the later lujavrites has also been noted during Th and $\mathrm{U}$ gamma-ray spectrometry surveys (Løvborg et al., 1971). In that study, large samples (rock surfaces about $800 \mathrm{~cm}^{2}$, equivalent to $14-21 \mathrm{~kg}$ ) were analysed and showed large variations between outcrops only a few metres apart. The modal and geochemical variability probably reflects a number of magmatic and post-magmatic processes.

In a detailed study of $\mathrm{Li}$ distribution in a drill core through aegirine lujavrite $\mathrm{I}$, the range in $\mathrm{Li}$ contents can be attributed to variations in the percentage of interstitial (Li-rich) residual liquid, late- to post-magmatic zeolitisation, contamination by naujaite xenoliths and localised shearing of arfvedsonite which has mobilised Li (Gwozdz \& Bailey, unpublished).

\section{Nodular lujavrites}

Nodular lujavrites occur in drill cores from the Tunugdliarfik-Agpat area (cf. Sørensen, 1962 , p. 78). The nodules were divided into cores and rims and, together with the host arfvedsonite lujavrite, were analysed for $\mathrm{Li}$ (Table 2). The results show that the host lujavrite has higher $\mathrm{Li}$ contents than the core of the nodules, the ratio ranging from 21 to 1.2. The acmite-rich rims also have lower $\mathrm{Li}$ contents than the host though their Li contents may be lower or higher than the core. These results are consistent with the suggestion that the nodules are relicts of naujaite xenoliths which ultimately reached a molten state, and thus occur as 'droplets' within the arfvedsonite lujavrite magma. Naujaite contains much lower Li contents (37-200 ppm, Gerasimovsky, 1969) than arfvedsonite lujavrite. It has also been proposed that the nodular structure is a result of liquid immiscibility (Sørensen, 1962).

The unusually high $\mathrm{Li}$ contents of the nodular lujavrites should be noted.

\section{Li in minerals}

$\mathrm{Li}$ contents of lujavrite minerals are given in Table 3. Arfvedsonite is the main carrier of $\mathrm{Li}$ in most of the lujavrites. The low $\mathrm{Li}$ contents of the aegirine lujavrites are at least partly related to their low abundance of arfvedsonite. This mineralogical control interferes with any steady increase in $\mathrm{Li}$ concentrations through the sequence of lujavrite varieties. Thus $\mathrm{Li}$ 


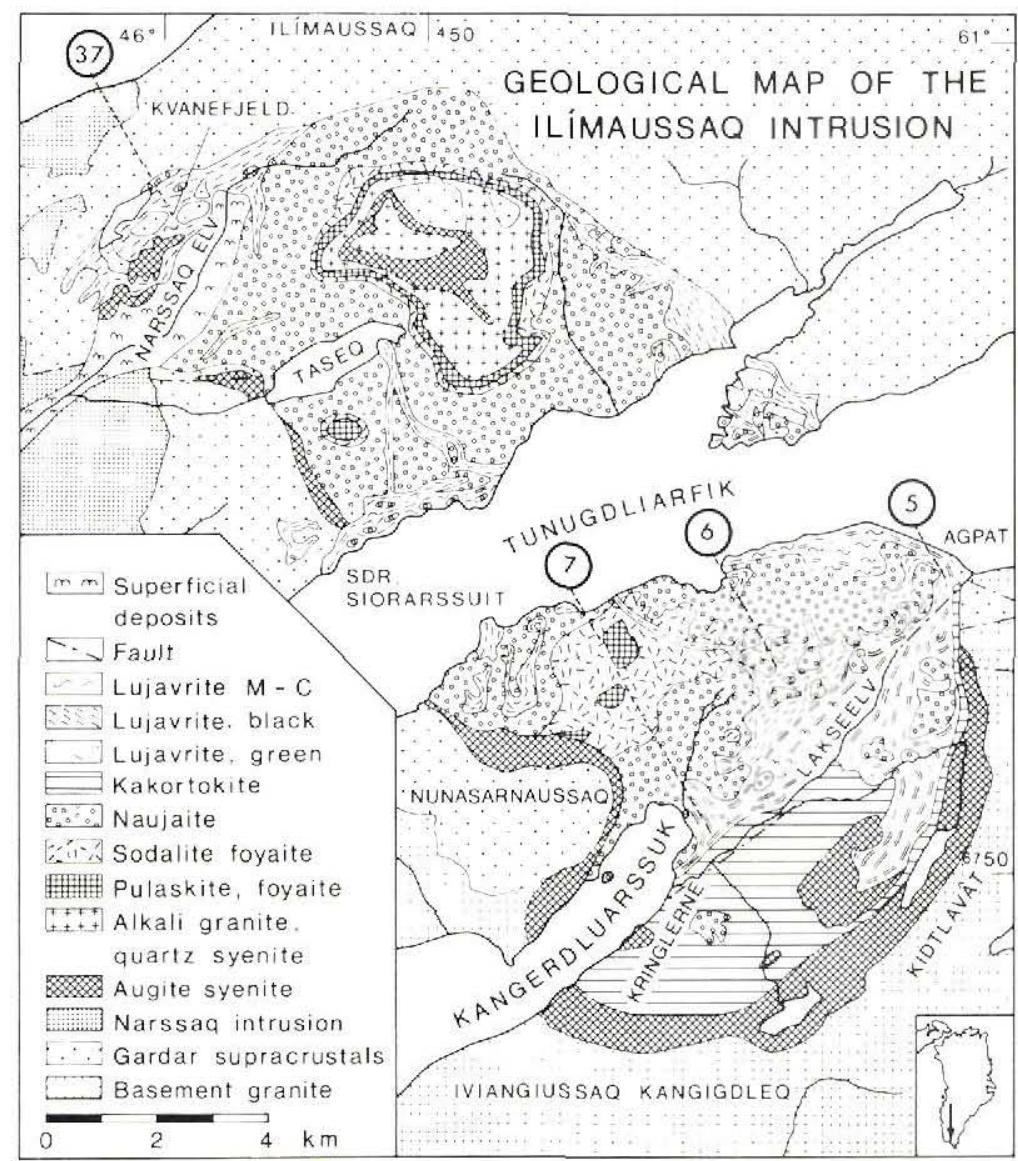

Fig. 3. Geological map of the Ilímaussaq intrusion with position of drill cores indicated. Lujavrite, green includes aegirine lujavrite I and later aegirine lujavrite. Lujavrite, black includes naujakasite-bearing lujavrite.

levels are unlikely to prove a sensitive geochemical indicator of lujavrite evolution. Work in progress with $\mathrm{S}$. Andersen and $\mathrm{H}$. Bohse suggests that element ratios such as $\mathrm{U} / \mathrm{Zr}, \mathrm{La} / \mathrm{Zr}$, $\mathrm{Y} / \mathrm{Zr}, \mathrm{La} / \mathrm{Y}$ and $\mathrm{Mn} / \mathrm{Fe}$ may prove more useful in this respect.

Contents of $\mathrm{Li}$ in other rock-forming lujavrite minerals are much lower than in arfvedsonite. Among the minor phases, villiaumite and steenstrupine have significant levels (about 200 ppm) of Li. Accessory Li-mica (polylithionite) is widely observed in lujavrite thin sections but its quantitative contribution to the total $\mathrm{Li}$ in lujavrite samples is difficult to assess.

The possibility that some $\mathrm{Li}$ in the lujavrites is located as loose intercrystalline films or as altered, readily extractable material was tested by leaching studies on the size fraction below $44 \mu \mathrm{m}$ in three lujavrite varieties (Table 4). The scatter of results reflects the small size and $\mathrm{Li}$ heterogeneity of the four $2 \mathrm{~g}$ splits taken from each sample, plus analytical imprecision. There is no indication that $\mathrm{Li}$ was extracted into any of the leaching solutions; it is thus dominantly fixed in the lattices of the minerals. 
Table 3. Li and $F$ values of minerals from Ilimaussaq lujavrites

\begin{tabular}{lrrr}
\hline & $\begin{array}{c}\text { Number of } \\
\text { samples }\end{array}$ & Li & F \\
\hline \multicolumn{1}{c}{$\begin{array}{l}\text { aegirine lujavrite I } \\
\text { later aegirine lujavrites }\end{array}$} & 1 & 2160 & 2200 \\
$\quad$ M-C lujavrite & 2 & 1530 & 1500 \\
Aegirine & 10 & 23 & 500 \\
Analcime + natrolite & 9 & 26 & $<500$ \\
Eudialyte & 8 & 13 & 600 \\
Microcline + nepheline & 5 & 5 & $<500$ \\
Naujakasite & 1 & 5 & - \\
Polylithionite* & 6 & 34200 & 74600 \\
Steenstrupine & 3 & 210 & 20200 \\
Villiaumite & 1 & 221 & $448100^{*}$ \\
\hline
\end{tabular}

\section{Comments on Li-F evolution}

Only preliminary comments can be made on the evolution of $\mathrm{Li}$ and $\mathrm{F}$ in the Ilímaussaq lujavrite sequence. Interpretation is hampered by the limited quality of the F results, especially at low contents and by the preliminary state of the petrologic examination of some of the lujavrites.

Table 4. Li contents in the minus 44 um fraction of three lujavrite types before and after leaching experiments

\begin{tabular}{lccc}
\hline Lujavrite type & Aegirine $I$ & Arfvedsonite & M-C \\
Core, depth $(\mathrm{m})$ & $7,176.5$ & $5,69.5$ & $37,92.28$ \\
\hline Untreated & 85 & 555 & 818 \\
Cold deionised water & 90 & 620 & 703 \\
Boiling deionised water & 120 & 473 & 1093 \\
Dilute sulphuric acid & 141 & 628 & 806 \\
\hline
\end{tabular}




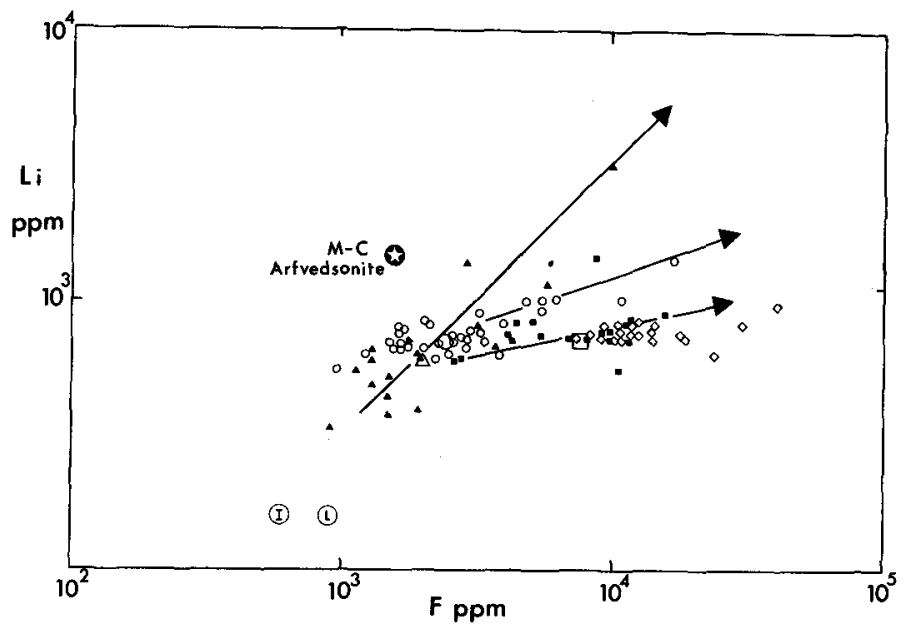

Fig. 4. Log-log relations for $\mathrm{Li}$ and $\mathrm{F}$ in selected lujavrites and in arfvedsonite from M-C lujavrite. (I) median, aegirine lujavrite I, (D) median, later aegirine lujavrites. Arfvedsonite lujavrites: $\Delta \mathbf{T u}$ nugdliarfik, Kvanefjeld, $\diamond$ villiaumite-rich (Kvanefjeld). O M-C lujavrite. Large symbols: corresponding. median compositions.

It has already been noted that both $\mathrm{Li}$ and $\mathrm{F}$ generally attain higher concentrations in the youngest lujavrites in agreement with the residual nature of these lujavrites. However, no single mechanism can explain in detail this build-up of $\mathrm{Li}$ and $\mathrm{F}$. Table 1 and fig. 4 emphasise that different linear $(\log -\log )$ correlations exist between $\mathrm{Li}$ and $\mathrm{F}$ in the various lujavrite types.

Aegirine lujavrite $I$ is considered to be a cumulate mush and cannot be equated with its immediate parental magma. The bulk of $\mathrm{Li}$ and $\mathrm{F}$ is held by arfvedsonite which crystallised from the interstitial residual liquid. Variations in $\mathrm{Li}$ and $\mathrm{F}$ reflect (1) variations in the amount of trapped residual liquid and (2) a variety of processes such as zeolitisation, shearing and Li-F metasomatism. The $\mathrm{Li}$ and $\mathrm{F}$ contents of the parental magma, the earliest of the lujavrite magmas, are unknown.

The later aegirine lujavrites are relatively poor in $\mathrm{Li}$. This probably reflects their low contents of arfvedsonite, the main $\mathrm{Li}$ carrier, but the reason for the low arfvedsonite contents is unknown. It is not clear whether these later aegirine lujavrites are equivalent to magmatic liquids; they may also be cumulus mushes.

The arfvedsonite lajavrites from the Tunugdliarfik area have a Li-F correlation coefficient of 0.85 and lie close to a $45^{\circ}$ line on the log-log diagram (fig. 4). This would normally be taken to suggest that these two elements had taken part in a process of crystal-liquid fractionation. It would be required that their bulk partition coefficients were virtually identical, possibly (though not necessarily) close to zero. This has not been confirmed, however, as the bulk Li-F chemistry of the cumulus phases is still unknown. The texture of these lujavrites indicate that some of them have been subject to deformation during crystallisation which may imply a loss of residual melts. Xenocrysts of naujaite minerals are locally important. It is therefore doubtful if the rocks studied are purely liquid fractionates. Variable addition of Li-mica to these rocks would produce virtually the same trend, though addition of several percent of Li-mica would be required by the high $\mathrm{Li}-\mathrm{F}$ samples and this feature has not been observed.

The Li-F correlation of the villiaumite-rich lujavrites is virtually identical with the line for the Kvanefjeld arfvedsonite lujavrites which also contain significant amounts of villiaumite. 
The correlation line observed is consistent with variable addition of $\mathrm{Li}$-poor $\mathrm{NaF}$. An independent line for villiaumite-free arfvedsonite lujavrites from Kvanefjeld has not yet been established.

The M-C lujavrites from Kvanefjeld, however, do exhibit an independent $\mathrm{Li}-\mathrm{F}$ correlation line. There is little evidence, at present, to suggest that any single mineral could generate such a 'mineral control line'. It is possible that the low Li-F end of the line reflects a mixture of arfvedsonite (Table 3) with some Li-, F-poor phases such as feldspar and zeolites. The high $\mathrm{Li}-\mathrm{F}$ end of the line perhaps represents lujavrite magma enriched in $\mathrm{Li}$ and $\mathrm{F}$. The fine-grained arfvedsonite lujavrites generally display igneous lamination and often deformational features. The M-C lujavrites are characterised by foyaitic textures which may imply in situ crystallisation of the melt. The Kvanefjeld lujavrites, including the M-C lujavrites, all belong to a high level in the intrusion, much higher than that at which the Tunugdliarfik lujavrites were formed. The Kvanefjeld lujavrites consolidated near the roof of the intrusion. The correlation lines of the Kvanefjeld lujavrites may therefore represent volatile-rich magmas, which are especially enriched in F. Given the coarse grain size of this lujavrite, and our relatively small samples, the variable admixture could to some extent be generated by inadequate sampling. These relations remain to be solved.

In summary, some of the $\mathrm{Li}-\mathrm{F}$ correlation lines found on log-log diagrams are suggestive of crystal fractionation mechanisms. In no case, however, have we yet confirmed this mechanism. $\mathrm{NaF}$ addition is locally important but more work is required to establish whether this enrichment is due to 'pneumatolytic' differentiation or to post-magmatic processes. The petrologic character of the various lujavrites appears to be very complex.

Finally, we note that the overall increase in $\mathrm{Li}$ and $\mathrm{F}$ through the lujavrite sequence is the opposite to the decrease observed in the preceding units of the Ilímaussaq intrusion (data of Gerasimovsky, 1969). A more precise and sensitive technique for $F$ analysis is urgently required and work is in progress on this problem at the Risø National Laboratory.

Acknowledgements. The $\mathrm{Li}$ and $\mathrm{F}$ analytical techniques were developed in the laboratories of $\mathrm{K}$. Heydorn of the Risø National Laboratory, Ris $\varnothing$. This analytical programme, and the computerised handling of the data, were supported by the Danish Natural Science Research Council. LSAs participation was made possible by a grant (501/2) from the Danish Natural Science Research Council.

\section{References}

Andersen, S. \& Bohse, H. 1978: Field work on the kakortokites and lujavrites in the Ilimaussaq intrusion, South Greenland. Rapp. Gronlands geol. Unders. 90, 73-75.

Demin, A. 1971: Detailed mapping in the southern part of the Ilímaussaq intrusion (Kangerdluarssuk fjord). Rapp. Grønlands geol. Unders. 35, 29-30.

Engell, J. 1973: A closed system crystal-fractionation model for the agpaitic Ilímaussaq intrusion, South Greenland with special reference to the lujavrites. Bull. geol. Soc. Denmark 22, 334-362.

Ferguson, J. 1970: The significance of the kakortokite in the evolution of the Ilímaussaq intrusion, South Greenland. Meddr Grønland 190(1), 193 pp.

Flanagan, F. J. 1976: Descriptions and analyses of eight new U.S.G.S. rock standards. Bull. U. S. geol. Surv. Prof. Pap. 840, 192 pp.

Gerasimovsky, V. I. 1969: Geochemistry of the Ilimaussaq Alkaline massif (in Russian). Moskva: Nauka, 174 pp.

Hamilton, E. I. 1964: The geochemistry of the northern part of the Ilimaussaq intrusion, S.W. Greenland. Bull. Grønlands geol. Unders. 42 (also Meddr Grønland 162,10) 104 pp. 
Heydorn, K., Skanborg, P.Z., Gwozdz, R., Schmidt, J. O. \& Wacks, M. E. 1977: Determination of lithium by instrumental neutron activation analysis. J. Radioanal. Chem. 37, 155-168.

Kunzendorf, H., Lundgaard, T., Rose-Hansen, J. \& Sørensen, E. 1973: Estimation of niobium and fluorine in the Kvanefjeld area, the Ilímaussaq intrusion south Greenland, with description of the methods used. Unpubl. int. GGU rep.

Løvborg, L., Wollenberg, H., Sørensen, P. \& Hansen, J. 1971: Field determination of uranium and thorium by gamma-ray spectrometry, exemplified by measurements in the Ilimaussaq alkaline intrusion, South Greenland. Econ. Geol. 66, 368-384.

Russel, B. G., Goudvis, R. G., Donnel, G. \& Levin, J. 1972: Preliminary report on the analysis of the six NIMROC geochemical standard samples. Rep. Nat. Inst. Met. Repub. S. Afr. 1351, 74 pp.

Semenov, E. I. 1969: Mineralogy of the Ilimaussaq alkaline massif (in Russian). Moskva: Nauka, $165 \mathrm{pp}$.

Sørensen, H. 1962: On the occurrence of steenstrupine in the Ilímaussaq massif, Southwest Greenland. Meddr Gronland 167, $251 \mathrm{pp}$.

Sørensen, H., Hansen, J. \& Bondesen, E. 1969: Preliminary account of the geology of the Kvanefjeld area of the Ilímaussaq intrusion, South Greenland. Rapp. Grønlands geol. Unders. 18, $40 \mathrm{pp}$.

Sørensen, H., Rose-Hansen, J., Nielsen, B. L., Løvborg, L., Sørensen, E. \& Lundgaard, T. 1974: The uranium deposit at Kvanefjeld, the Ilímaussaq intrusion, South Greenland. Geology, reserves and beneficiation. Rapp. Grønlands geol. Unders. 60, $54 \mathrm{pp}$.

Steele, T. W., Wilson, A., Goudvis, R. G. et al. 1978: Analyses of the NIMROC reference samples for minor and trace elements. Rep. Nat. Inst. Met. Repub. S. Afr. 1945, 230 pp.

Institut for Petrologi, University of Copenhagen,

$\varnothing$ ster Voldgade 10,

DK-1350 Copenhagen $K$. 